\title{
NIETZSCHE E A IDIOTIA DIVINA DE JESUS
}

\author{
Renato Nunes Bittencourt* \\ seminarioppgf@yahoo.com.br
}

RESUMO $O$ artigo versa sobre a distinção axiológica estabelecida por Nietzsche entre a prática evangélica de Jesus e a distorção da mesma pela institucionalização da moralidade cristã. Através das indicações de Nietzsche, realiza-se uma interpretação imanente da mensagem religiosa de Jesus, que fez de sua doutrina uma possibilidade de se alcançar a beatitude no âmbito da própria vida, e não uma promessa para além do mundo; mais ainda, a comprovação de que a genuína prática cristã se fundamentava numa valoração amoral, destituída de qualquer qualidade normativa.

Palavras-chave Nietzsche, Jesus, idiota, prática evangélica, beatitude.

ABSTRACT The article turns on the axiologic distinction established by Nietzsche enters the gospelical practical of Jesus and the distortion of the same one for the institutionalization of the Christian morality. Through the indications of Nietzsche, one becomes fulfilled an interpretation immanent of the religious message of Jesus, who made of its doctrine a possibility of if reaching the beatitude in the scope of the proper life, and a promise does not stop beyond the world; more still, the evidence of that genuine practical Christian if based on an amoral valuation, destitute of any normative quality.

Keywords Nietzsche, Jesus, idiot, evangelical practice, beatitude.

* Doutor em Filosofia pelo Programa de Pós-Graduação em Filosofia da Universidade Federal do Rio de Janeiro.

KRITERION, Belo Horizonte, nº 123, Jun./2011, p. 105-119. 
Podemos afirmar que problematização nietzschiana sobre o âmago da obra evangélica de Jesus de Nazaré encontra a sua expressão mais apurada em $O$ Anticristo; nesse ensaio percebemos uma análise tipológica da personalidade de Jesus que permite a formulação de uma interpretação sobre a práxis crística a partir de uma perspectiva livre de valorações morais, tal como o estabelecimento eclesiástico cristão iria posteriormente promover, em nome da satisfação dos seus projetos normativos destoantes em relação ao sentido originário da doutrina evangélica. Para Nietzsche, aquela que seria a autêntica figura histórica de Jesus estaria fixada em seu tipo psicológico, pois este permaneceu incólume diante das interpretações moralistas concedidas pela tradição teológica cristã, mantendo-se assim independente dos traços estranhos e incongruentes com que a instituição cristã o teria desfigurado. Tal como Nietzsche salienta,

O que me importa é o tipo psicológico do Redentor. Afinal, ele pode estar contido nos evangelhos apesar dos evangelhos, ainda que mutilado ou carregado de traços alheios: como o de Francisco de Assis está conservado em suas lendas, apesar de suas lendas. Não a verdade quanto ao que fez, o que disse, como realmente morreu; mas a questão de o seu tipo ser concebível, de haver sido "transmitido" (NIETZSCHE, 2007, p.35)

Ao delinear o tipo psicológico de Jesus, Nietzsche descarta as definições de "herói" e "gênio", propostas por Ernest Renan, célebre historiador francês que dedicara grande parte de sua vida intelectual ao estudo do Cristianismo nas suas conjunturas históricas, teológicas e filosóficas. Para Nietzsche, essa perspectiva defendida pelo pensador francês seria uma grande estultícia, pois a vida e a obra evangélica de Jesus contrariavam toda a ideia de "herói" ou "gênio" (NIETZSCHE, 2007, p. 35-36). Nietzsche demonstra continuamente uma grande aversão pela obra de Renan, conforme podemos ver em Crepúsculo dos Ídolos, onde Nietzsche diz: "Renan - Teologia, ou a corrupção da razão pelo 'pecado original'(o cristianismo)" (NIETZSCHE, 2006, p. 63). Todavia, é importante ressaltar que Nietzsche reflete nas suas críticas tardias ao Cristianismo alguns pontos cruciais da historiografia renaniana, mas é justamente essa fixação do historiador francês pelas categorias de "herói" e "gênio, esses grosseiros erros do "bufão" in psychologicis (NIETZSCHE,

1 Essa citação nietzschiana é uma prova textual que demonstra a influência exercida por Renan na formulação da sua "Psicologia do Redentor". Renan (1915, p. XVII-XVIII), afirma: "Que os evangelhos são uma parte lendários, isso é evidente, porque estão cheios de milagres e de sobrenatural; mas há lendas de lendas. Ninguém duvida das passagens principais da vida de São Francisco de Assis, embora a sua vida apresente a cada passo o sobrenatural". 
2007, p. 35), que motivam as irônicas diatribes nietzschianas. Uma leitura atenta da obra de Renan nos permite constatar a sua evidente competência na narrativa historiográfica da gênese do movimento cristão. Renan elabora uma compreensão da natureza histórica de Jesus que apresenta rupturas com o quadro teológico estabelecido; certamente foram essas intuições que influenciaram positivamente a formulação nietzschiana da "psicologia crística", ainda que o filósofo tenha manifestado publicamente apenas a sua aversão aos pretensos erros de interpretação de Renan, talvez uma espécie de estratégia intelectual para demarcar as suas próprias posições filosóficas em relação ao pensador francês.

Após as colocações precedentes, vejamos então o cerne dessa polêmica: Renan denomina Jesus como o "Herói da Paixão": “[...] É agora o incomparável Herói da Paixão, o fundador dos direitos da consciência livre, o perfeito modelo, que todas as almas amarguradas que sofrem hão de estudar para se fortificarem e consolarem" (RENAN, 1915, p. 312). Renan faz ainda referência a uma "vontade heroica" de Jesus (1915, p. 373). Ora, pela palavra "herói" pressupõe-se uma pessoa dotada de ímpeto de ação prática, capaz de transformar extensivamente uma dada situação, numa batalha, numa circunstância histórico-social. Um herói caracteriza-se pelo projeto de superar os seus adversários mediante o uso da força física e também da inteligência.

Pensando conforme as valorações nietzschianas, é praticamente inconcebível visualizarmos a imagem de Jesus como um adepto da luta armada em prol do estabelecimento da justiça entre os homens, pois tal procedimento contrariaria os seus preceitos harmoniosos. O projeto evangélico de Jesus não consistia no questionamento e na supressão da ordem política estabelecida, mas na instauração do estado de alegria mediante a prática doadora de amor, circunstância que retira a pessoa das experiências banais da realidade. Nessas condições, aquilo que Jesus efetivamente propunha era a transformação do enfoque valorativo do indivíduo em relação àquilo que ele realmente considerava como os seus objetivos existenciais no seu cotidiano. A disposição beatífica de Jesus ocorre em uma dimensão para além da esfera social das relações políticas, pois estas, em decorrência dos sectários e dos interesses particulares, podem prejudicar o estabelecimento de uma vivência harmoniosa conveniente no estabelecimento de uma relação interpessoal. Tal problema, portanto, contraria a doutrina evangélica de Jesus, que é um processo de transmutação dos afetos ressentidos em uma experiência de abertura para o outro, numa mística interação doadora de vida, de alegria. A não-reatividade de Jesus diante das inúmeras atribulações impostas por seus "adversários" representaria, na verdade, a capacidade do Nazareno em superar 
todo tipo de ressentimento, pois em decorrência de sua manifestada beatitude, nenhum estímulo externo agressivo pode retirá-lo desse estado interativo com o "divino".

Outro elemento problemático do estudo de Renan decorreria da sua tentativa de enquadrar a personalidade de Jesus na categoria de "Gênio". Com efeito, Renan apresenta a ideia de que Jesus seria um "Homem de Gênio"(RENAN, 1945, p. 46). Nietzsche contrapõe-se a essa tese renaniana por considerar de forma peremptória que a ideia de "gênio" não condizia com a realidade judaica. Podemos esclarecer essa perspectiva da seguinte maneira: a formação do homem de gênio pressupõe a disposição intrínseca da cultura da qual se faz parte para o florescimento de uma série de elementos que concedam ao indivíduo e ao seu povo a realização de obras intelectuais e artísticas que expressam a singularidade do seu criador. Jesus de forma alguma se encontrava associado aos valores culturais que possibilitam o surgimento do tipo "gênio", pois o Nazareno se expressava através de verdades interiores, não de conceitos lógicos demonstrativos, à maneira de um dialético que pretende persuadir os seus interlocutores através da racionalidade discursiva. Jesus é indiferente ao âmbito da "cultura" estabelecida socialmente, pois a sua vivência espiritual foi adquirida mediante a sua interiorização psicoafetiva, cujo resultado mais evidente consistiu na supressão de toda atividade mental dedutiva. Esse processo intuitivo de desvelamento de uma verdade interior, para muito além da esfera da lógica, da racionalidade, não pode ser adquirida pela cultura formal e pela erudição, mas pelo "coração", pois é uma experiência da interioridade. Desse modo, "Jesus não nega a 'cultura', pois nem mesmo a conhece como tal, ela não teria nenhum significado para ele" (FREZZATTI JR., 2006, p.166).

Nietzsche pretende então conceder uma definição categórica para a personalidade de Jesus, definição essa que seria a senha para a compreensão do grande enigma que foi a vida do Nazareno: este seria um "idiota", não na sua depreciativa conotação usual do senso comum, mas no sentido original do termo grego, ou seja, de uma pessoa indiferente aos valores estabelecidos usualmente pela sociedade, pela civilização, pela coletividade humana, por não compactuar com as circunstâncias que envolvem a realidade cotidiana (NIETZSCHE, 2007, p. 35-36). Nessas circunstâncias, ao delinear o tipo psicológico de Jesus através do conceito de "idiota", Nietzsche, em um fragmento póstumo 15 [9] da primavera de 1888, demonstra uma importante filiação a Dostoiévski, cujo pensamento lhe serve de suporte para a sua contraposição à cristologia romântica de Renan: 
Eu conheço apenas um psicólogo que viveu num mundo onde o Cristianismo é possível, onde um Cristo pode surgir a qualquer momento. É Dostoievski. Ele adivinhou Cristo: - e ele permaneceu instintivamente protegido da representar esse tipo com a vulgaridade de Renan (NIETZSCHE, 1980, p.

Dostoiévski, no seu romance $O$ Idiota, através da figura do príncipe Míchkin, apresenta a beatífica personalidade do indivíduo incapaz de compreender e adquirir domínio cabal sobre as vicissitudes externas que o rodeiam. Sufocado em uma atmosfera social marcada pelo oportunismo dos indivíduos e pelo ímpeto destes em fazer imperar os seus desejos egoístas, a mescla de inocência e sublimidade de Míchkin tornam-se disposições que se voltam contra ele mesmo, por sua inaptidão em pertencer ao jogo de manipulações dos seus interlocutores. Somente quem se destaca da moral de rebanho é capaz de intuir a essência crística e a distorção operada pelo estabelecimento eclesiástico ao longo da história. Com efeito, o tipo "idiota" está mais próximo da vivência evangélica do que a falsa consciência devota "cristã", que prega um Cristianismo deformado, prenhe de calúnia e deturpado, ou seja, um verdadeiro “Anticristo” (DOSTOIÉVSKI, 2002, p. 606).

O "idiota" é uma pessoa caracteristicamente singular no mundo, pois a sua axiologia não corresponde ao padrão estabelecido pela moda e pelos costumes sociais. ${ }^{2}$ Supostamente tolo diante de uma dimensão social que norteia seus valores por critérios quantitativos, o "idiota" possui uma forte disposição para a "nobreza" de espírito, nobreza que, aliás, pode também perfeitamente se manifestar na sua vida como uma dádiva material, um título honorífico. Tal como esclarece Marco Vannini,

Por isso não há dúvida que a pesquisa fisiológica (e psicológica) sobre Jesus que terminou na definição de 'idiota', subentenda uma avaliação positiva sua, em estreito paralelismo com o significado dostoievskiano da palavra - tão positiva que o próprio Nietzsche acaba identificando-se com a essa figura de Jesus-Idiota (VANNINI, 2003, p. 512)

Conforme argumenta Anton Uhl, "neste mundo de Dostoiévski reencontra Nietzsche o Cristianismo mais autêntico, que, segundo sua consideração,

2 Vejamos as interpretações de dois estudiosos de Nietzsche sobre a questão da "idiotia" de Jesus: Martin Dibelius afirma: "Temos que nos remeter aqui ao grego idiotes, bem como idiota, do latim, que dele derivou, como designação de homem privado em oposição a homem de Estado, leigo em oposição a versado, ignorante em oposição a erudito"(DIBELIUS, 1944, p. 65-66); Para Salaquarda, "Nietzsche entende 'idiota' essencialmente nos termos de seu sentido grego, isto é, como designação para um 'homem apolítico', um cidadão privado, impedido de participar dos negócios do Estado" (SALAQUARDA, 1998, p. 270). 
Paulo perverteu tão completamente: incapaz de encontrar dentro de si o "Reino de Deus", ele o transferiu para o "Além", ensinou o juízo e criou um Cristianismo que faz guerra, condena, tortura, jura, odeia" (UHL, 1981, p.53). É nesse contexto que podemos entender a ideia nietzschiana de que "a vida acaba onde o "Reino de Deus" começa" (NIETZSCHE, 2006, p. 36); com efeito, o estado jubiloso apresentado por Jesus como uma experiência possível de ser vivenciada por toda pessoa que plasma a sua existência através dos afetos beatíficos, da alegria e da comunhão, no contexto da ideologia sacerdotal cristã, se distorce numa promessa metafísica de cunho moral. Nessas condições, se o "Reino de Deus" enunciado por Jesus é a expressão de uma experiência sagrada de beatitude na própria imanência da vida, o "Reino de Deus" postulado pela moralidade cristã é uma instância alheia ao mundo concreto, prenhe de caracteres escatológicos. Talvez uma das chaves que nos permitam decifrar essa ideia de "idiotia" na vivência crística encontre-se, no contexto da narrativa evangélica, no momento em que Jesus diz: "Meu reino não é deste mundo. Se meu reino fosse desse mundo, meus súditos teriam combatido para que eu não fosse entregue aos judeus. Mas meu reino não é daqui" (João, 18, 36).

Ao contrário das esperanças messiânicas dos judeus de uma instauração de um onipotente Reino Divino na Terra como um Estado político propriamente dito, o "Reino de Deus" de Jesus está além de qualquer definição concreta, e não encontra, portanto, qualquer paralelo com a ordem extensiva da realidade. A partir dessas características é que se estabelece uma axiologia da "idiotia" na prática evangélica, mediante a negativa de qualquer pretensão política acerca do advento do "Reino de Deus", em verdade um estado destituído de temporalidade e de concretude material. A tipologia do "idiota" representa assim uma pessoa de caráter "extra-social", que não se enquadra nos critérios normativos da coletividade. ${ }^{3}$ Acompanhando a argumentação de MüllerLauter, podemos até mesmo afirmar que a atividade evangélica de Jesus e seus próprios valores intrínsecos estavam além de toda a moral (1971, p.88).

Cabe ressaltar que na própria narrativa bíblica encontramos a corroboração da ideia de extramoralidade, quando Jesus, ao ser denominado "bom" por um homem admirado por suas qualidades, rechaça tal titulação, afirmando que apenas "Deus" pode ser considerado como tal. ${ }^{4}$ Trata-se de mais um indício da "idiotia" evangélica de Jesus, distanciando-se da visão moralista que o

3 Essa perspectiva também é defendida por BARROS (2002, p. 63)

4 'Certo homem de posição lhe perguntou: 'Bom Mestre, que devo fazer para herdar a vida eterna?' Jesus respondeu: 'Por que me chamas bom? Ninguém é bom, senão só Deus!' (Lucas, 18, 18-19). 
sistema religioso tradicional impõe aos seguidores. Segundo a interpretação de Eugen Biser acerca da interpretação nietzschiana sobre a práxis evangélica de Jesus, "o Cristianismo originário é a infância livre de toda discórdia e contradição e acolhida ao mesmo tempo no espiritual, um ser-homem que descansa ingenuamente em si mesmo" (BISER, 1974, p.122)

Nietzsche considera Jesus um exemplo de "espírito livre", pois o Nazareno, no decorrer de sua práxis evangélica, não dependeu da ordem moral estabelecida para elaborar a sua axiologia crística. "Seria possível, com alguma tolerância da expressão, chamar Jesus 'um espírito livre' - ele não faz caso do que é fixo: a palavra mata, tudo o que é fixo mata" (NIETZSCHE, 2007, p. 39). A noção de 'espírito livre', em Nietzsche, representa o indivíduo que conseguiu se desvencilhar do peso opressivo da moral estabelecida e se propõe então a criar valores novos que a colocam numa situação de extemporaneidade diante da tradição cultural em vigor, tal como o próprio subtítulo de Humano, demasiado humano evidencia, 'um livro para espíritos livres’ (NIETZSCHE, 2003). Essa associação terminológica se justifica pelo fato de que Jesus propôs uma experiência religiosa que se distanciava da moralidade judaica desgastada pelo formalismo dos seus sacerdotes. A perpetuação dessa tradição vazia motivou o afastamento dos fiéis da prática religiosa efetiva, ocorrendo assim o distanciamento do homem em relação ao âmbito divino por causa da hierarquia sacerdotal; esta, ao invés de servir de catalisador do processo de interação do devoto para com a esfera divina, na verdade acaba por desligar essa conexão sagrada, estabelecendo uma imagem de Deus como uma personalidade transcendente ao mundo que somente pode ser alcançada mediante o cumprimento de ritos específicos.

Contrapondo-se a essa concepção normativa que rejeita a singularidade da experiênciareligiosa, Jesus, como um “espírito livre", visaria odesenvolvimento de uma experiência vivência da alegria, capaz de proporcionar a geração de sentimentos afirmativos, que suprimiriam as vivências tristes e depressivas da afetividade humana. $\mathrm{O}$ amor crístico, configurado pela própria experiência da mensagem evangélica, viabilizaria o nascimento de um sentimento de comunhão através da descoberta da unidade mística fundamental, que proclama a ideia de que todos são "filhos de Deus", cada um é igual a todos, sem qualquer restrição, tal como destacado por Nietzsche (2007, p. 36).

A ideia que se faz de Jesus como aquele que sofreu para redimir a humanidade das suas faltas, assim como da imagem da Paixão como recurso destinado a exercer efeito moral sobre a consciência dos fiéis não corresponde ao genuíno espírito crístico, que suprime justamente toda noção de dívida moral a ser quitada pelo ser humano diante de Deus ao longo de sua história de 
redenção. A Paixão, que representaria a culminação gloriosa da obra evangélica de Jesus, na qual se demonstra a beatitude na sua forma mais extraordinária, se torna o mecanismo teológico que reteria a individualidade dos fiéis diante dos seus parâmetros normativos. Para Nietzsche,

Esse "portador da boa nova" morreu como viveu, como ensinou - não para "redimir os homens", mas para mostrar como se deve viver. A prática foi o que ele deixou para a humanidade: seu comportamento ante os juízes, ante os esbirros, ante os acusadores e todo tipo de calúnia e escárnio - seu comportamento na cruz. Ele não resiste, não defende seu direito, não dá um passo para evitar o pior; mais ainda, ele provoca o pior... E ele pede, ele sofre, ele ama com aqueles, naqueles que lhe fazem mal... As palavras que ele diz ao ladrão na cruz contêm todo o evangelho. "Este foi verdadeiramente um homem divino, um filho de Deus" - diz o ladrão. "Se sentes isso - responde o Salvador - "então estás no paraíso, és também um filho de Deus..." Não defender-se, não encolerizar-se, não atribuir responsabilidade... mas tampouco resistir ao mau - amá-lo... (NIETZSCHE, 2007, p. 42).

Podemos defender a tese de que a compreensão do espírito crístico originário está no preceito de "não resistirmos ao homem mau" (Lucas, 5, 39), ou seja, não levantarmos oposições violentas contra nossos detratores mesmo nas condições mais desfavoráveis; afinal, a vivência evangélica impede que o indivíduo faça qualquer oposição a uma situação de desagravo, e o fato do indivíduo lutar por seus "direitos" e tomar parte na ordem estabelecida é contradizer a disposição existencial proporcionada pela aplicação da disposição evangélica. A capacidade beatífica de não se resistir ao "mal" significa a supressão de todo tipo de reatividade e violência diante dos desagravos cotidianos, experiência típica da "idiotia" religiosa. A formulação do final da citação precedente é extremamente semelhante à que Nietzsche utiliza no Ecce Homo para definir o conceito de amor fati: "Minha fórmula para a grandeza do homem é amor fati: nada querer diferente, seja para trás, seja para a frente, seja em toda a eternidade. Não suportar apenas o necessário, menos ainda ocultá-lo - todo idealismo é mendacidade ante o necessário mas amá-lo... (NIETZSCHE, 2001, p. 51). Uma pergunta então é inevitável: porventura Nietzsche identifica na Paixão de Jesus uma espécie de vivência do amor fati? Com efeito, o Nazareno afirmou a dor na Cruz sem formular qualquer imprecação contra os seus agressores; mais ainda, nada fez para

5 Nietzsche cometera um equívoco de citação ao colocar na boca do ladrão (Lucas, 23, 39-43), a frase na qual se proclama a divindade de Jesus, quando na verdade teria sido um centurião romano que fazia a guarda que enunciara essa sentença, após a morte de Jesus. (Mateus, 27, 54). Todavia, no contexto de sua interpretação da vivência crística, pouca diferença isso faz. Em qualquer circunstância, se evidencia a epifania evangélica de Jesus. 
afastar de si esse destino, obtendo assim uma morte beatífica, sem a erupção de qualquer ressentimento.

Por sua vez, o ato de se interpretar a Paixão de Jesus como a esperança de redenção mediante o sacrifício do "Cristo-Cordeiro de Deus" que tomou os nossos pecados, denota a incompreensão da mensagem evangélica originária, que, malgrado o fato de ter sofrido modificações ao gosto escuso dos detentores do discurso eclesiástico oficial, pode, todavia, ser apreendida intuitivamente pela vivência psicológica (GIACÓIA JÚNIOR, 1997, p. 48). Como Nietzsche ressalta, a morte de Jesus é utilizada pela casta sacerdotal como instrumento de reparação moral, deturpando assim o sentido originário dessa experiência de comunhão com o sagrado:

- O destino do evangelho foi decidido com a morte - foi pendurado na "cruz..." Somente com a morte, essa morte inesperada, ignóbil, somente a cruz, geralmente reservada para a canaille [canalha] - somente esse horrível paradoxo pôs os discípulos ante o verdadeiro enigma: "quem foi esse? O que foi isso?." - O sentimento abalado e profundamente ofendido, a suspeita de que tal morte poderia ser a refutação de sua causa, a terrível interrogação "por que justamente assim?" - é um estado que se compreende muito bem. Tudo aí tinha de ser necessário, ter sentido, razão, suprema razão; o amor de um discípulo não conhece acaso. Apenas então o abismo se abriu: "quem o matou? quem era seu inimigo natural?" - essa questão irrompeu como um raio. Resposta: o judaísmo dominante, sua classe mais alta. Nesse instante sentiramse em revolta contra a ordem, entenderam Jesus, em retrospecto, como em revolta contra a ordem. Até ali faltava, em seu quadro, esse traço guerreiro, essa característica de dizer o Não, fazer o Não; mais até, ele era o contrário disso. Evidentemente, a pequena comunidade não compreendeu o principal, o que havia de exemplar nessa forma de morrer, a liberdade, a superioridade sobre todo sentimento de ressentiment [ressentimento]: - sinal de como o entendia pouco! Jesus não podia querer outra coisa, com sua morte, senão dar publicamente a mais forte demonstração, a prova de sua doutrina... Mas seus discípulos estavam longe de perdoar essa morte - o que teria sido evangélico no mais alto sentido; ou mesmo de oferecer-se para uma morte igual, com meiga e suave tranquilidade no coração... Precisamente o sentimento mais "inevangélico", a vingança, tornou a prevalecer. A questão não podia findar com essa morte: necessitava-se de "reparação", "julgamento" (- e o que pode ser menos evangélico do que "reparação", "castigo", "levar a julgamento"!). Mais uma vez a expectativa popular de um Messias apareceu em primeiro plano; enxergouse um momento histórico: o "reino de Deus" como ato final, como promessa! Mas o evangelho fora justamente a presença, a realização, a realidade desse "reino de Deus"... Pela primeira vez carrega-se todo o desprezo e amargor contra fariseus e teólogos para o tipo do mestre - tornando-o assim um fariseu e teólogo! Por outro lado, a frenética veneração dessas almas totalmente saídas dos eixos não mais tolerou a evangélica identificação de cada um como filho de Deus, que Jesus havia ensinado: sua vingança foi exaltar extravagantemente Jesus, destacá-lo de si: assim como os judeus de outrora, por vingança contra os inimigos, haviam separado de si e erguido às alturas o seu. $\mathrm{O}$ único Deus e o único filho de Deus: ambos produtos do ressentiment... (NIETZSCHE, 2007, p. 46-48). 
Nietzsche também considera haver uma incongruência na ideia da Ressurreição, pois a visão de mundo cristã fez da crença nesse acontecimento condição sine qua non para o estabelecimento de sua experiência religiosa, quando, na verdade, a história dos Evangelhos por si só já deveria servir de instrumento capaz de reforçar as disposições beatíficas dos fiéis. O caráter mais elevado da prática crística não depende da ocorrência de eventos que sirvam de confirmação da autoridade sagrada de Jesus, procedimento tão bem articulado pelo discurso teológico cristão, mas da capacidade de viver efetivamente na sua esfera transfiguradora. Parafraseando o discurso evangélico, podemos dizer que o sistema sacerdotal, além de não conseguir estabelecer conexão com a dimensão divina, não deixa que os demais também o façam. ${ }^{6}$ Conforme argumenta Nietzsche,

- A partir de então houve um problema absurdo: "como podia Deus permitir isso?" A perturbada razão da pequena comunidade deu-lhe uma resposta assustadoramente absurda: Deus deu seu filho em sacrifício para o perdão dos pecados. De uma só vez acabou-se o evangelho! O sacrificio expiatório, e em sua forma mais bárbara e repugnante, o sacrifício do inocente pelos pecados dos culpados! Que pavoroso paganismo! - Jesus havia abolido o próprio conceito de "culpa" - ele negou todo abismo entre Deus e homem, ele viveu essa unidade de Deus e homem como sua "boa nova"... E não como prerrogativa! - A partir de então entra no tipo do Redentor, passo a passo, a doutrina do julgamento e do retorno, a doutrina da morte como uma morte sacrificial, a doutrina da ressurreição, com a qual é escamoteado o conceito de "beatitude", a única realidade do evangelho - em prol de um estado posterior à morte!... Com a insolência rabínica que sempre o caracteriza, Paulo racionalizou esta concepção, esta obscenidade de concepção, da seguinte forma: "Se Cristo não ressuscitou de entre os mortos, é vã a nossa fé" [1 Coríntios, 15,14], - E de uma só vez o evangelho se tornou a mais desprezível das promessas não realizáveis, a desavergonhada doutrina da imortalidade pessoal... O próprio Paulo ainda a ensinava como recompensa!... (NIETZSCHE, 2007, p. 48).

A ideia da Ressurreição tornou-se então um instrumento de dominação teológica, e não a certeza da perpetuação da "vida", para além da "morte" das suas figurações singulares. A própria ideia de "hora da morte" tão tradicional para a moralidade cristã não faz sentido algum para a experiência evangélica, talvez seja mesmo a sua antagonista. O memento mori é um sintoma de adoecimento psíquico e afastamento da beatitude crística, pois esta se encontra numa esfera axiológica que rompe com os paradigmas extensivos de "vida" e "morte". Para Nietzsche, 
[...]. Todo o conceito de morte natural está ausente no evangelho: a morte não é uma ponte, uma passagem, ela não está presente, pois pertence a um mundo inteiramente outro, apenas aparente, útil apenas para signos. A "hora da morte" não é um conceito cristão - a "hora", o tempo, a vida física e suas crises não chegam a existir para aquele que ensina a "boa nova"... (NIETZSCHE, 2007, p. 41-42)

A experiência cristã original realiza-se na própria imanência e nos permite ver que o Reino dos Céus não está acima do mundo físico, da Terra, mas se encontra imediatamente unido a ela. É por isso que, de acordo com os Evangelhos, Jesus teria afirmado que o "Reino de Deus está dentro de nós." (Lucas 17, 21). Ao interpretar esse fragmento evangélico, Nietzsche realiza uma espécie de paráfrase da mensagem do Nazareno, considerando que

[...]. O "reino do céu" é um estado de coração - não algo que virá "acima da Terra" ou "após a morte" [...] O Reino de Deus não é nada que se espere; não possui ontem nem depois de amanhã, não virá em "mil anos" - é a experiência de um coração; está em toda parte, está em nenhum lugar... (NIETZSCHE, 2007, p.41-42).

O "Reino dos Céus" é intrinsecamente desprovido de extensividade, e essa sua característica primordial torna-o uma sagrada experiência jubilosa desvinculada da participação pessoal nos parâmetros morais estabelecidos pela ordem sacerdotal, circunstância que seria, na verdade, a sua tristonha supressão. Nietzsche focaliza a sua perspectiva valorativa para o caráter de pura intensidade na visão deste referido "Reino dos Deus", que consiste assim na própria ausência da ideia de fixidez e de delimitação extensiva e temporal diante da imagem que a Cristandade faz do postulado "Plano Divino". Presente intensivamente em cada pessoa que vivencia o estado crístico, o "Plano Divino" não se manifesta extensivamente na realidade social, mas é um desabrochar singular no íntimo de cada pessoa. Nietzsche exclui então da ideia estabelecida do "Reino de Deus" a expectativa teleológica de um poder divino a se sobrepor sobre a ordem do mundo, para julgar toda a humanidade por seus atos ao longo das eras (NIETZSCHE, 2007, p. 21). O "Reino de Deus" tal como revelado metaforicamente por Jesus não possui traços milenaristas e não é um evento escatológico, mas sim uma vivência na "eternidade" do afeto de amor e comunhão dos homens. Jesus demonstrara para aqueles que se abriram sinceramente aos seus ensinamentos que para alguém se sentir no "Céu" e para se sentir "eterno" é necessário o desenvolvimento de uma nova compreensão da existência, que por sua vez gera um novo comportamento, justamente livre de todo entravamento, temor ou rancor diante das condições adversas do mundo circundante. Para Jesus, o "Reino de Deus" não pode ser pensado como promessa de um paraíso ultramundano, mas como vivência 
plena e atemporal do amor e da renúncia a toda oposição, a toda forma de ressentimento (GIACÓIA JÚNIOR, 1997, p. 39).

A alegria e o amor dissolvem as limitações pessoais que impedem o afloramento da consciência de que a vida no júbilo crístico torna alguém "eterno" (NIETZSCHE, 2007, 41). O "Reino de Deus", tal como compreendido por Nietzsche, encontra-se na disposição afetiva do indivíduo capaz de vivenciar a realidade circundante através da perspectiva da alegria e do amor. Tudo passa a fazer parte de uma grande unidade imanente, permeada pelo espírito de alegria que unifica todos os seres: trata-se da beatitude e da inocência do homem livre do peso do ressentimento e do medo, instrumentos de dominação moral utilizados pela casta sacerdotal cristã.

Quando Jesus enuncia aos seus discípulos a sentença "Eu e o Pai somos um" (João 10,30), dá testemunho de um nítido monismo, pois o distanciamento entre o divino e o humano, tão destacado pela casta sacerdotal judaica como forma de motivar o estristecimento do fiel, em verdade inexiste. Ora, dizer que o estado beatífico promove a identificação imediata entre o humano e o divino é uma ideia desfavorável para os detentores do poder eclesiástico, decorrendo daí os ressentimentos dos fariseus frente Jesus, que apregoava a possibilidade de cada um compreender a unidade com o "Pai". Nietzsche considera que, com a palavra "Filho", expressa-se a entrada no sentimento geral de transfiguração de todas as coisas (a beatitude), e com a palavra "Pai", esse sentimento mesmo, o sentimento de eternidade, de perfeição (NIETZSCHE, 2007, p. 41). Por meio dessas palavras, Nietzsche enfatiza precisamente a relação de unicidade entre ambas as esferas, intrinsecamente complementares, ainda que expressem perspectivas axiológicas distintas. Esse monismo que associa ontologicamente "Pai" e "Filho" proporciona a integração de ambos numa única pessoa, e é o amor que gera essa associação, que somente pode ser vivenciada pelo "coração", pois é uma experiência extrarracional. A atividade evangélica de Jesus consistiu justamente em motivar nos seus seguidores a capacidade de cada um alcançar esse estado sagrado de júbilo, pois essa relação sagrada suprime da vida humana todo sentimento de temor e tristeza. Conforme os elucidativos comentários de Oswaldo Giacóia Jr.,

Essa prática de interiorização do Reino de Deus implica, senão uma negação explícita, doutrinária e formal da Igreja entendida como realidade exterior, organizada segundo princípios, hierarquias, regramentos, pelo menos sua superação e supressão necessárias na práxis, no seio de uma vivência quotidiana de comunhão universal com o "Pai" e o "Próximo" que abole todas as distâncias (GIACÓIA JR., 1997, p. 77). 
A beatitude vivenciada por Jesus não combina, de forma instintiva, com hierarquias consolidadas pela autoridade social; a disposição sagrada vivenciada por Jesus prima pela capacidade singular de cada um se libertar dos entraves afetivos que prejudicam a participação nessa experiência de amor divino. Esse "estado de coração" manifestar-se-ia em toda pessoa que viesse a despertar um conjunto de afetos benéficos para o desenvolvimento saudável da vida, tais como o amor incondicional diante do outro e a magnânima capacidade de perdoar as ofensas sofridas, suprimindo-se assim os estados rancorosos da afetividade, que afastam o indivíduo da esfera crística (Mateus, 5, 43-44). Para Nietzsche,

A vida do Redentor não foi senão essa prática - sua morte também não foi senão isso... Ele não tinha mais necessidade de nenhuma fórmula, de nenhum rito para o trato com Deus - nem mesmo oração. Acertou contas com toda a doutrina judaica da penitência e reconciliação; sabe que apenas com a prática de vida alguém pode sentir-se 'divino', 'bem-aventurado', 'evangélico', a qualquer momento um 'filho de Deus'. Não a “penitência”, não a oração pelo perdão' é um caminhos para Deus: somente a prática evangélica conduz a Deus, ela justamente é Deus - O que foi liquidado com o evangelho foi o judaísmo dos conceitos "pecado", "perdão dos pecados", "fé", "redenção pela fé" - toda a doutrina eclesiástica judia foi negada na "boa nova" (NIETZSCHE, 2007, p.40-41).

Imerso nessa dimensão beatífica, o ser humano, para relacionar-se com o âmbito divino, não necessitaria nem de fórmulas preestabelecidas, muito menos ritos, pois somente através da prática de vida, tal como Nietzsche salienta, alguém pode se sentir "divino", "bem aventurado", "evangélico", um "Filho de Deus", vivendo em estado de júbilo e livre do sentimento de pecado e de toda coerção moral. Na psicologia do "evangelho" não há os conceitos de culpa ou de castigo (NIETZSCHE, 2007, p. 40). Para quem estabelece uma interação imediata com o "divino", os rituais e as orações tornam-se elementos secundários, pois não são práticas imprescindíveis para que possa ocorrer o contato com a esfera sagrada, pois o indivíduo já se encontra nessa esfera sagrada, ele na verdade vive nela. Para que se estabeleça essa vivência transfiguradora, somente é necessário o amor, a quietude íntima, jamais a adequação individual a preceitos normativos e fórmulas vazias. Não há, tampouco, a necessidade da crença numa dimensão espiritual ontologicamente e axiologicamente superior ao mundo em que vivemos, pois que na própria experiência religiosa podemos nos preencher afetivamente com a alegria da interação com a divindade. Nessa perspectiva, Nietzsche, demonstrando uma surpreendente visão sobre a experiência religiosa proporcionada pelo espírito crístico, afirma que 
O profundo instinto para como alguém deve viver a fim de sentir-se "no céu", sentir-se "eterno", enquanto, conduzindo-se de qualquer outro modo, não se sente absolutamente no céu: apenas esta é a realidade psicológica da "redenção": - uma nova conduta, não uma nova fé... (NIETZSCHE, 2007, p. 41).

A "Psicologia do Redentor" nietzschiana representa, portanto, a possibilidade de instauração de uma vivência religiosa destituída da virulência do ressentimento e de toda coerção normativa na consciência daquele que, mediante o amor crístico, se relaciona imediatamente ao "divino", emancipado da moral sacerdotal e dos seus efeitos deletérios na possibilidade de formulação de uma prática religiosa alegre, para além de "Bem" e de "Mal". Ao invés de ensinar uma fé específica, Jesus mostrou como experimentar a eternidade dentro dos limites da finitude da vida humana, tal como destacado por Peter Berkowitz (2000, p. 148). Nessas condições, a idiotia intrínseca da práxis evangélica de Jesus representa a possibilidade de se vivenciar uma experiência religiosa no âmbito da "extramoralidade", circunstância que rompe com o tradicional delineamento escatológico que a instituição teológica cristã lhe inseriu no decorrer da história. Nietzsche, em sua reflexão cristológica sobre a experiência sagrada de Jesus, promove uma nova possibilidade de interpretação da prática cristã, transvalorada dos seus anódinos elementos coercitivos que distorceram o espírito originário da mensagem evangélica e sua inocente beatitude.

\section{Referências bibliográficas}

BARROS, Fernando de Moraes. A Maldição Transvalorada: o problema da civilização em O Anticristo de Nietzsche. São Paulo: Discurso Editorial, 2002.

BERKOWITZ, Peter. Nietzsche - La Ética de um inmoralista. Trad. de María Condor. Madrid: Teorema, 2000.

BÍBLIA DE JERUSÁLEM. Direção editorial de Paulo Bazaglia. São Paulo: Paulus, 2002.

BISER, Eugen. Nietzsche y la destruccion de la conciencia cristiana. Trad. Esp. de Josué Enzaguirre. Salamanca: Ediciones Sigueme, 1974.

DIBELIUS, Martin. "Der psychologische Typus des Erlösers bei F. Nietzsche". In: Deutsche Vierteljahrsschrift für Literaturwissenschaft und Geshichte, $\mathrm{n}^{\circ} 22,1944, \mathrm{p}$. 61-91.

DOSTOIÉVSKI, Fiódor. O Idiota. Trad. de Paulo Bezerra. São Paulo: Ed. 34, 2002. FREZZATTI JR, Wilson Antonio. A Fisiologia de Nietzsche: a superação da dualidade cultura/biologia. Ijuí: Ed.Unijuí, 2006.

GIACÓIA JR, Oswaldo. Labirintos da alma-Nietzsche e a auto-supressão da Moral. Campinas: Ed. Unicamp, 1997. 
MÜLLER-LAUTER, Wolfgang. Nietzsche: Seine Philosophie der Gegensätze und die Gegensätze seiner Philosophie, Berlin/New York: Walter de Gruyter, 1971.

NIETZSCHE, Friedrich. Sämliche Werke. Kritische Studienausgabe. Edição organizada por Giorgio Colli e Mazzino Montinari. 15 Vols. Berlin/München/New York: Walter de Gruyter/DTV, 1980.

. O Anticristo / Ditirambos de Dionísio. Trad. de Paulo César de Souza. São Paulo: 2007.

. Crepúsculo dos Ídolos ou como se filosofa com o martelo. Trad. de Paulo César de Souza. Companhia das Letras: São Paulo: 2006.

. Ecce Homo - como alguém se torna o que se é. Trad. de Paulo César de Souza. São Paulo: Companhia das Letras, 2001.

. Humano, demasiado humano: um livro para espíritos livres. Trad. de Paulo César de Souza. São Paulo: Companhia das Letras, 2003.

RENAN, Ernest. São Paulo. Trad. de Thomaz da Fonseca. Porto: Livraria Chardon de Lelo e Irmão, 1945.

. Vida de Jesus. Trad. de Eduardo Augusto Salgado. Porto: Livraria Chardon de Lelo e Irmão, 1915.

SALAQUARDA, Jörg. "Dionysus versus the Crucified One: Nietzsche's Understanding of the Apostle Paul". In: CONWAY, Daniel (Ed.). Nietzsche: critical assessments. Londres/Nova York: Routledge, 1998, p. 266-291.

UHL, Anton. "Dor por Deus e dor pelo Homem: Nietzsche e Dostoiévski", In: Nietzsche e o Cristianismo. Trad. de Waldemar do Amaral. Petrópolis: Vozes, 1981, p.43-55.

VANNINI, Marco. "Friedrich Nietzsche - Uma relação de amor-ódio com Jesus e uma surpreendente tentativa de identificação" In. ZUCAL, Silvano (Org.). Cristo na Filosofia Contemporânea - Vol. I: de Kant a Nietzsche. Trad. de José R. Vidigal. São Paulo: Paulus, 2003, p. 499-529. 
